\title{
Short communication: Effect of whey protein addition and transglutaminase treatment on the physical and sensory properties of reduced-fat ice cream
}

\author{
Erfan Danesh, ${ }^{*}$ Mostafa Goudarzi, $†$ and Hossein Jooyandeh*1 \\ *Department of Food Science and Technology, Ramin Agricultural and Natural Resources University of Khuzestan, Ahvaz, Iran 6341773637 \\ †Department of Food Science, Technology and Engineering, University College of Agriculture and Natural Resources, University of Tehran, Karaj, \\ Iran 315877787
}

\begin{abstract}
The effects of whey protein addition and transglutaminase treatment, alone and in combination, on the physical and sensory properties of reduced-fat ice cream were investigated. Adding whey protein with or without enzyme treatment decreased melting rate, overrun, and hardness of the reduced-fat ice cream; however, the enzyme-treated sample had a higher melting rate and overrun and softer texture. Whey protein-fortified samples showed higher melting resistance, but lower overrun and firmer texture compared with the enzyme-treated sample without added whey protein. Whey protein addition with or without transglutaminase treatment caused an increase in apparent viscosity and a decrease in flow index of the reduced-fat ice cream; nevertheless, the flow behavior of full-fat sample was most similar to the enzyme-treated reduced-fat sample with no added whey protein. Descriptive sensory analyses showed that neither whey protein addition nor transglutaminase treatment significantly influenced the flavor and odor of reduced-fat ice cream, but they both noticeably improved the color and texture of the final product. The results of this study suggest that whey protein addition with transglutaminase treatment improves the physical and sensory properties of reduced-fat ice cream more favorably than does whey protein addition or transglutaminase treatment alone.
\end{abstract}

Key words: reduced-fat ice cream, whey protein, transglutaminase, physical property

\section{Short Communication}

Awareness of the relationship between diet and health has stimulated interest in foods with less fat. However, reduced-fat foods do not enjoy wide popularity because of poor sensory properties (McClements, 2015). Reduced-fat ice creams usually suffer from undesirable

Received December 30, 2016.

Accepted March 24, 2017.

${ }^{1}$ Corresponding author: hosjooy@yahoo.com flavor, low melting resistance, and high firmness (Roland et al., 1999). Whey proteins have been widely used as fat replacer in dairy products, including ice cream (Ohmes et al., 1998; Prindiville et al., 2000; Yilsay et al., 2006; Akalin et al., 2008). Whey proteins could simulate the role of fat in establishing the texture and flavor of ice cream, which is attributed to their ability to interact with water, proteins, and flavor compounds (Prindiville et al., 2000). Whey proteins, owing to their water-holding properties, could prevent increasing the ice phase volume of ice cream and thereby improve the texture (Ruger et al., 2002). The water-holding capacity of whey protein powders ranges from 70 to $147 \mathrm{~g}$ of water/100 g of powder, or 33 to $180 \mathrm{~g}$ of water/100 g of protein (Zayas, 1997); thermal denaturation of whey proteins may even lead to a 4 -fold increase in their water-holding capacity (Zayas, 1997). Therefore, incorporation of whey proteins, especially in their denatured form, into the formulation of ice cream is expected to lower the free water available for freezing, and thus reduce the ice phase volume. The more ice in the ice cream, the greater the resistance to an applied force and the harder the sample (Muse and Hartel, 2004). In their denatured state, whey proteins interact with each other and caseins micelles, forming a protein network that, in turn, leads to increased viscosity of ice cream mix (Relkin and Sourdet, 2005). As the viscosity in ice cream mix is raised, the resistance to melting and the smoothness of body increases, whereas the whipping rate decreases (Ruger et al., 2002).

Transglutaminase treatment of milk proteins is another strategy to produce reduced-fat ice cream with improved textural properties. Transglutaminase (TGase, EC 2.3.2.13) is an acyltransferase that catalyzes the cross-linking of most food proteins including milk proteins through formation of $\varepsilon$-( $\gamma$-glutamyl $)$ lysine intra- and intermolecular isopeptide bonds (Motoki and Seguro, 1998). The protein polymers formed via the catalytic action of TGase can perform similar functional properties as fat. It is believed that fat globules, as either individually distinct globules or clusters of globules, mechanically obstruct ice crystal 
growth in the ice cream matrix and thereby provide a smoother texture for ice cream (Marshall and Arbuckle, 1996). Daw and Hartel (2015) determined the particle size distribution of ice cream and pointed out that the peak appearing at $1 \mu \mathrm{m}$ represents the individual fat globules in the ice cream mix and the peak beginning somewhere between 3 and $10 \mu \mathrm{m}$ represents the fat clusters in the melted ice cream. Considering the mean size of milk proteins, which is in the range of 0.3 to 0.4 $\mu \mathrm{m}$ in ice cream mix (Daw and Hartel, 2015), it seems logical to hypothesize that the enzymatically formed protein polymers, which are most probably much larger than the individual whey protein molecules or casein micelles, could act as physical barriers, reducing the probability of collisions between ice crystals. These large protein polymers could also behave in the same way as hard spheres, showing high resistance to flow and thereby increasing the viscosity of ice cream (Rossa et al., 2012); the higher the viscosity, the slower the melting rate of ice cream. Rossa et al. (2012) reported that TGase-induced polymerization of milk proteins led to increased overrun and melting resistance and decreased hardness for the reduced-fat ice cream samples. No previous studies have reported on enzymatic incorporation of deliberately added whey proteins to milk into ice cream formulation by TGase. The aim of our study was, thus, to evaluate the effects of adding whey proteins and TGase on the physical and sensory properties of reduced-fat ice cream.

Raw skim bovine milk (protein $3.19 \pm 0.05 \%$, fat $0.52 \pm 0.07 \%$, moisture $91.23 \pm 0.19 \%$, and $\mathrm{pH} 6.65 \pm$ 0.03 ), skim milk powder (protein $30.97 \pm 0.19 \%$, fat 0.1 $\pm 0.01 \%$, and moisture $4.68 \pm 0.1 \%$ ) and pasteurized cream (fat $30.27 \pm 0.29 \%$ ) were supplied by Khuzestan Pegah Dairy Company (Shush, Iran). Whey protein isolate (WPI; protein $92 \pm 2 \%$, fat $0.2 \%$, lactose $0.2 \%$, ash $4 \%$, and moisture content $6 \%$, as determined by manufacturer) and microbial transglutaminase (Probind CH, nominal activity: 80-125 EU) were procured from Arla Foods Ingredients (Videbaek, Denmark) and BDF Natural Ingredients (Girona, Spain), respectively. Carboxymethyl cellulose and emulsifier E471 were purchased from Sunrose (Tokyo, Japan) and Puratus (Grand-Bigard, Belgium), respectively. Sucrose and vanillin were obtained from local markets.

Ice cream mixes were formulated to contain $10 \%$ milk fat (full-fat control); $5 \%$ milk fat (reduced-fat control), $5 \%$ milk fat plus whey protein isolate (R-WPI), $5 \%$ milk fat plus TGase (R-TG), and 5\% milk fat plus whey protein isolate and TGase (R-WPI+TG). Formulas for the mixes are shown in Table 1. Raw skim milk was mixed with pasteurized cream at room temperature and warmed up to $50^{\circ} \mathrm{C}$ to ensure proper mixing. At this point, the mix was incorporated with
$4 \mathrm{~g} / \mathrm{L}$ of WPI, rapidly heated to $78^{\circ} \mathrm{C}$ and kept at this temperature for $15 \mathrm{~min}$ for denaturation of whey proteins. After cooling to $40^{\circ} \mathrm{C}$, TGase was added to the mix at a ratio of $4 \mathrm{U} / \mathrm{g}$ of protein. The TGase concentrations were calculated considering the protein content of milk, quantified by the Kjeldahl method (AOAC International, 2005), plus that of the deliberately added WPI to milk. The enzymatic treatment was continued for $90 \mathrm{~min}$ and then stopped by heating the reaction mixture at $80^{\circ} \mathrm{C}$ for $2 \mathrm{~min}$. Subsequently, dry ingredients, including skim milk powder, sucrose, vanillin, emulsifier, and stabilizer, were added and mixed. The skim milk powder was added to increase the DM content of the ice cream mix (Karaman et al., 2014). Each mix was pasteurized at $80^{\circ} \mathrm{C}$ for $25 \mathrm{~s}$ and then homogenized for 1 min using an Ultra-Turrax T25 homogenizer at 2,029 $\times g$ (IKA Instruments, Staufen im Breisgau, Germany). The mixes were rapidly cooled to $4^{\circ} \mathrm{C}$ and aged at the same temperature for $24 \mathrm{~h}$. The aged mixes were frozen using a batch freezer (Feller ice cream maker, model IC 100; Feller Technologic GmbH, Dusseldorf, Germany) for 35 min, packaged into 120$\mathrm{mL}$ lidded plastic containers, hardened, and stored in a freezer at $-25^{\circ} \mathrm{C}$ until analyses.

The flow behavior of unfrozen mixes was evaluated using a Physica MCR 301 rheometer (Anton-Paar GmbH, Graz, Austria) equipped with a circulating cooling bath at $4.0 \pm 0.1^{\circ} \mathrm{C}$. Samples were subjected to a shear rate linearly increasing from 2 to $100 \mathrm{~s}^{-1}$ in $14 \mathrm{~min}$ and the shear stresses were recorded at 30-s intervals. Consistency coefficient $(\mathrm{k})$ and flow behavior index (n) were calculated by fitting shear rate and shear stress data to power law model. Apparent viscosity of the samples was computed at a shear rate of $50 \mathrm{~s}^{-1}$.

A 120-g block of ice cream sample was placed on a wire screen located on top of a beaker and allowed to melt at room temperature $\left(22 \pm 1^{\circ} \mathrm{C}\right)$. The weight of drainage recorded at 10-min intervals was plotted against time and the melting rate $(\mathrm{g} / \mathrm{min})$ was calculated from the slope of the melting chart (Elsayed Metwally, 2007).

The overrun was calculated on a weight basis according to Adapa et al. (2000), as

$$
\% \text { Overrun }=\frac{\text { weight of mix }- \text { weight of ice cream }}{\text { weight of ice cream }} \times 100 \text {. }
$$

The hardness of ice cream samples was measured using a TA.XT2i Texture Analyzer (Stable Micro Systems, Goldalming, UK) equipped with a $50 \mathrm{~N}$ load cell and a 6-mm diameter cylindrical probe. The ice creams were cut to fill a cylindrical cup of $4.5 \mathrm{~cm}$ diameter to a depth of $30 \mathrm{~mm}$ (Lim et al., 2008) and tempered at 
Table 1. Ice cream mix composition

\begin{tabular}{|c|c|c|c|c|c|}
\hline \multirow[b]{2}{*}{ Ingredient } & \multicolumn{5}{|c|}{ Treatment $^{1}$} \\
\hline & $\mathrm{F}$ & $\mathrm{R}$ & R-WPI & R-WPI+TG & R-TG \\
\hline Milk fat $(\%, w t / w t)$ & 10 & 5 & 5 & 5 & 5 \\
\hline Skim milk powder $(\%, \mathrm{wt} / \mathrm{wt})$ & 7 & 7 & 7 & 7 & 7 \\
\hline Sucrose $(\%$, wt $/$ wt) & 17 & 17 & 17 & 17 & 17 \\
\hline Vanillin (\%,wt/wt) & 0.1 & 0.1 & 0.1 & 0.1 & 0.1 \\
\hline Emulsifier $(\%$, wt $/ w t)$ & 0.2 & 0.2 & 0.2 & 0.2 & 0.2 \\
\hline Stabilizer $(\%, \mathrm{wt} / \mathrm{wt})$ & 0.2 & 0.2 & 0.2 & 0.2 & 0.2 \\
\hline Whey protein $(\mathrm{g} / \mathrm{L})$ & - & - & 4 & 4 & - \\
\hline Transglutaminase (U/g) & - & - & - & 4 & 4 \\
\hline TS (\%,wt/wt) & 42.92 & 38.84 & 39.24 & 39.40 & 39.00 \\
\hline
\end{tabular}

room temperature $\left(22 \pm 1^{\circ} \mathrm{C}\right)$ for $5 \mathrm{~min}$ before they were penetrated to a depth of $15 \mathrm{~mm}$ at a speed of $2.0 \mathrm{~mm} / \mathrm{s}$. The hardness was determined as the peak compression force during penetration (BahramParvar et al., 2013).

Sensory attributes of ice cream samples were evaluated by a trained panel of 10 members, including students of Ramin Agricultural and Natural Resources University. The panelists were trained for $2 \mathrm{~h}$ to evaluate the ice cream samples for flavor, odor, color, texture, and overall acceptability on a scale from 1 to 9 (Karaman et al., 2014). The grades of the scale for evaluation of sensory attributes were extremely dislike (1), very dislike (2), moderately dislike (3), slightly dislike (4), not dislike not like (5), slightly like (6), moderately like (7), very like (8), and extremely like (9) (Goudarzi et al., 2015). Panelists were encouraged to write additional comments on the evaluation worksheet.

Each experiment was performed at least in duplicate and measurements performed at least in triplicate. Data were reported as means \pm standard error and were analyzed by one-way ANOVA using SAS software version 9.3 (SAS Institute, Cary, NC). Dunnett's multiple comparison test was used to determine statistically significant differences among the means.

The power law model well described the flow behavior of ice cream mixes with a high correlation coefficient (Table 2). The flow behavior index was in the range of 0.56 to 0.66 , indicating the pseudoplastic behavior of all the samples (Table 2; Figure 1A). It was observed that either enzymatic (R-WPI+TG) or nonenzymatic (RWPI) incorporation of whey proteins as a fat replacer into the formulation of reduced-fat ice cream mix markedly increased the consistency coefficient and decreased the flow behavior index (Table 2). It is thought that addition of thermally unfolded whey protein into ice cream mix with or without TGase treatment leads to formation of high-molecular-weight protein polymers, which simulate the role of fat in establishing the texture of ice cream. In their native state, whey proteins do not interact with each other or with casein micelles because of their compact globular structures. However, thermal treatment could destabilize the native whey protein structure and facilitate intra- and intermolecular interactions of milk proteins by exposing glutamine residues as acyl donors in a TGase crosslinking reaction (Rossa et al., 2011) as well as reactive thiol groups, which can form disulfide links with other reactive thiol groups and through thiol group-disulfide bridge exchange reactions (Vasbinder, 2002). The WPI-fortified samples showed higher consistency and lower flow indexes than the R-TG ice cream mix (Table 2), which could be due to the formation of the larger protein polymers in these 2 samples. Rossa et al. (2012) assumed that large polymer molecules show higher resistance to flow but tend to disentangle, and possibly align in the flow field, as the shear rate increases. The lower apparent viscosity and stronger shear-thinning behavior of R-WPI+TG compared with R-WPI (Table 2 ) could be explained by differences in type and degree of protein-protein interactions in these 2 samples.

The viscosity of ice cream mix is highly correlated with its physical properties, including melting resistance; the higher the viscosity, the greater is the melting resistance (Ruger et al., 2002). Our results showed that the control reduced-fat sample with the lowest viscosity melted the fastest, followed by R-TG, R-WPI+TG, R-WPI, and control full-fat samples (Figure 1B); the latter 2 samples did not show a significant difference $(P>0.05)$. Similar to the melting rate, the overruns of all reduced-fat samples were higher than that of control full-fat ice cream (Figure 1C). It is said that low viscosity of an ice cream mix is favorable for the incorporation of air (Adapa et al., 2000), as observed for the control reduced-fat ice cream. However, the reduced-fat samples added with WPI or TGase showed higher over- 

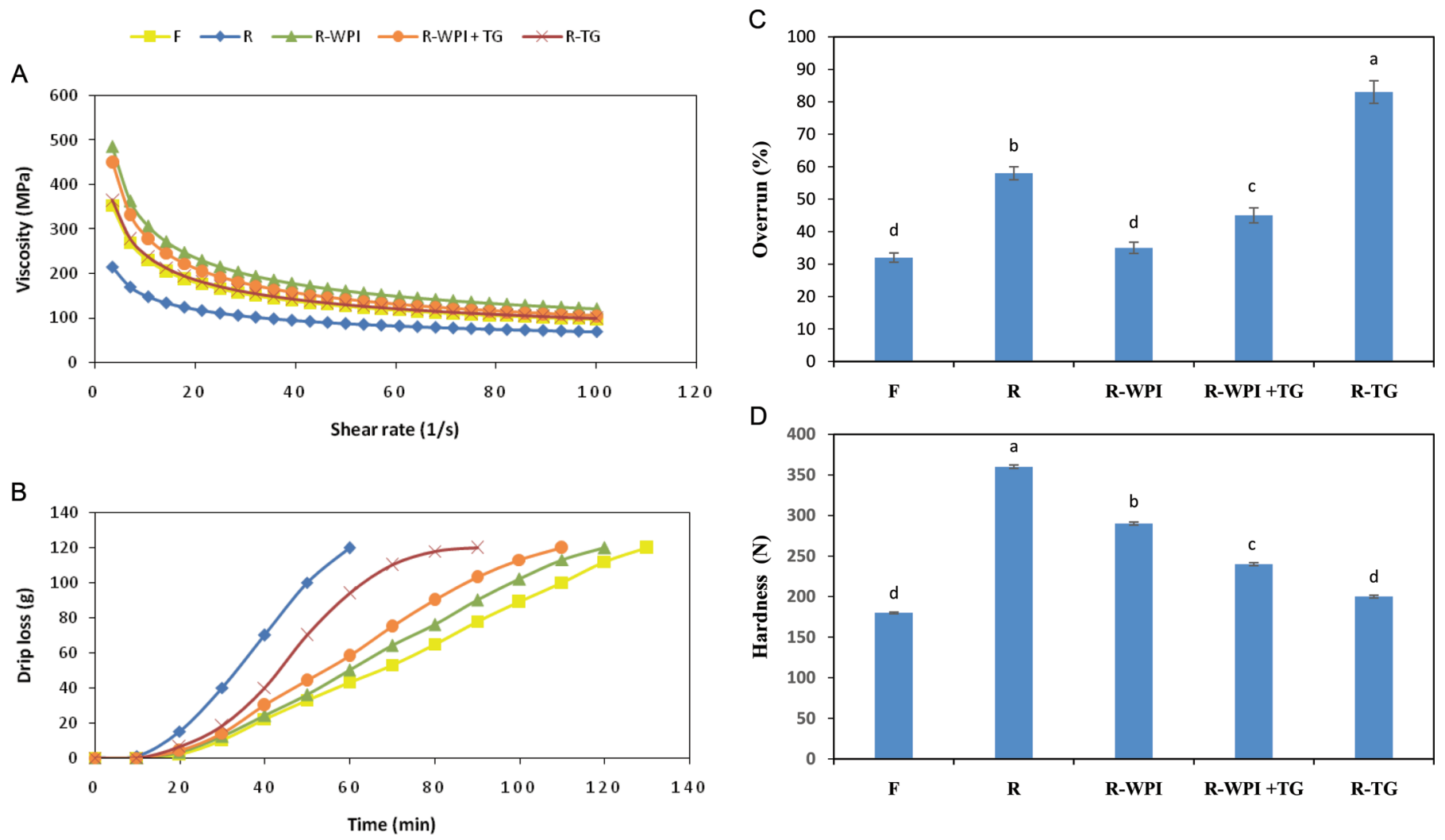

Figure 1. Flow behavior (A), melting rate (B), overrun (C), and hardness (D) of ice cream samples. Different letters (a-d) stand for significant differences between treatments $(P<0.05) . \mathrm{F}=$ control full-fat ice cream; $\mathrm{R}=$ control reduced-fat ice cream; $\mathrm{R}$-WPI $=$ reduced-fat ice cream with whey protein; R-WPI+TG $=$ reduced-fat ice cream with whey protein and transglutaminase, R-TG $=$ reduced-fat ice cream with transglutaminase. Color version available online.

run than control full-fat sample despite having higher viscosity. This can be attributed to disulfide-mediated or enzyme-catalyzed formation of protein networks with higher capability to retain air in these samples. Nevertheless, it should be taken into account that the highly strengthened protein networks may show greater resistance to extension, leading to lower incorporation of air into the ice cream mix and, thus, lower overrun. The more rigid protein network of R-WPI and
R-WPI+TG samples could also be responsible for their higher hardness compared with R-TG (Figure 1D). Rossa et al. (2012) speculated that formation of a more cohesive protein network in ice cream samples treated with TGase led to reduction of ice crystallization, and thereby a decrease in hardness of ice cream. Accordingly, the softer texture of R-WPI+TG compared with R-WPI ice cream (Figure 1D) may imply that the enzymatic method of incorporating the whey protein as

Table 2. Flow behavior characteristics of ice cream mixes ${ }^{1}$

\begin{tabular}{|c|c|c|c|c|}
\hline Treatment $^{2}$ & $\begin{array}{c}\text { Apparent viscosity } \\
(\mathrm{MPa} / \mathrm{s})\end{array}$ & $\mathrm{K}\left(\mathrm{Pa} / \mathrm{s}^{\mathrm{n}}\right)$ & $\mathrm{n}$ & $\mathrm{R}^{2}$ \\
\hline $\mathrm{F}$ & $126.13 \pm 4.6^{\mathrm{c}}$ & $0.58 \pm 0.01^{\mathrm{c}}$ & $0.61 \pm 0.01^{\mathrm{b}}$ & 0.9995 \\
\hline $\mathrm{R}$ & $87.27 \pm 2.8^{\mathrm{d}}$ & $0.33 \pm 0.01^{\mathrm{d}}$ & $0.66 \pm 0.01^{\mathrm{a}}$ & 0.9982 \\
\hline R-WPI & $160.51 \pm 6.3^{\mathrm{a}}$ & $0.83 \pm 0.01^{\mathrm{a}}$ & $0.58 \pm 0.01^{\mathrm{c}}$ & 0.9995 \\
\hline R-WPI+TG & $148.21 \pm 5.7^{\mathrm{b}}$ & $0.79 \pm 0.01^{\mathrm{b}}$ & $0.56 \pm 0.01^{\mathrm{c}}$ & 0.9925 \\
\hline R-TG & $130.48 \pm 5.2^{\mathrm{c}}$ & $0.60 \pm 0.01^{\mathrm{c}}$ & $0.61 \pm 0.01^{\mathrm{b}}$ & 0.9956 \\
\hline
\end{tabular}

${ }^{\mathrm{a}-\mathrm{d}}$ Values with different superscripts in the same column differ $(P<0.05)$.

${ }^{1} \mathrm{~K}=$ consistency index; $\mathrm{n}=$ flow behavior index; $\mathrm{s}^{\mathrm{n}}=$ second flow behavior index.

${ }^{2} \mathrm{~F}=$ control full-fat ice cream; $\mathrm{R}=$ control reduced-fat ice cream; $\mathrm{R}$-WPI = reduced-fat ice cream with whey protein; R-WPI+TG = reduced-fat ice cream with whey protein and transglutaminase, $\mathrm{R}-\mathrm{TG}=$ reduced-fat ice cream with transglutaminase. 
a fat replacer into the formulation of reduced-fat ice cream mix was more effective in providing a uniform emulsion for the final product than nonenzymatic one.

As expected, the control full-fat ice cream received significantly higher flavor score than the reduced-fat samples (Figure 2), which is in accordance with the results of Akbari et al. (2016). It has been reported that vanilla flavor intensity and creaminess are diminished as the fat content of ice cream decreases (Roland et al., 1999). In the present study, the sensory panel stated that the WPI-fortified samples had stronger vanilla flavor and greater creaminess compared with other reduced-fat ice cream samples; however, they complained about the adverse effect of whey proteins on ice cream flavor. This may somewhat justify our observation on insignificant differences in flavor scores for the reduced-fat samples (Figure 2). The results showed that neither whey protein addition nor TGase treatment noticeably influenced the sensory scores for odor; however, they significantly improved the color desirability of reduced-fat ice cream (Figure 2). Of the reduced-fat samples, the R-WPI+TG ice cream received the highest score for color, followed by $\mathrm{R}$ WPI, R-TG, and control reduced-fat samples (Figure 2 ). Reducing the fat content of ice cream is usually concomitant with a decrease in whiteness (Roland et al., 1999; Yilsay et al., 2006). On the other hand, large protein polymers formed in the presence of added whey proteins or TGase enzyme could simulate the role of milk fat globules in scattering the light, providing a higher whiteness for the reduced-fat ice cream. Hence, it seems logical to hypothesize that the higher color scores of ice creams containing whey protein or TGase compared with the control reduced-fat sample resulted from higher whiteness of these samples. The panelists determined that fat reduction significantly decreased texture desirability of ice cream. Conversely, whey protein addition and TGase treatment, alone or in combination, improved the texture of reduced-fat ice cream. The order of reduced-fat ice cream samples for texture scores was the same as that for color scores (Figure 2); that is, the TGase-treated sample with no added whey protein received a lower score for texture than whey protein-containing samples in spite of the fact that it had the lowest hardness of the reduced-fat samples (Figure 1D). As the viscosity dictates the overall perception of ice cream texture (Aime et al., 2001), the higher viscosity of whey protein-containing samples (Table 2) might be a reason for their higher texture scores compared with other reduced-fat samples. The reduced-fat samples fortified with whey protein or treated with TGase received significantly higher scores for overall acceptability than the control reduced-fat ice cream; however, no reduced-fat samples were scored as favorably as the control full-fat ice cream. Of the reduced-fat samples, R-WPI+TG ice cream had the

\section{$\Delta \mathrm{F} \quad$ 日R 四R-WPI 固-WPI+TG 圈 $\mathrm{R}-\mathrm{TG}$}

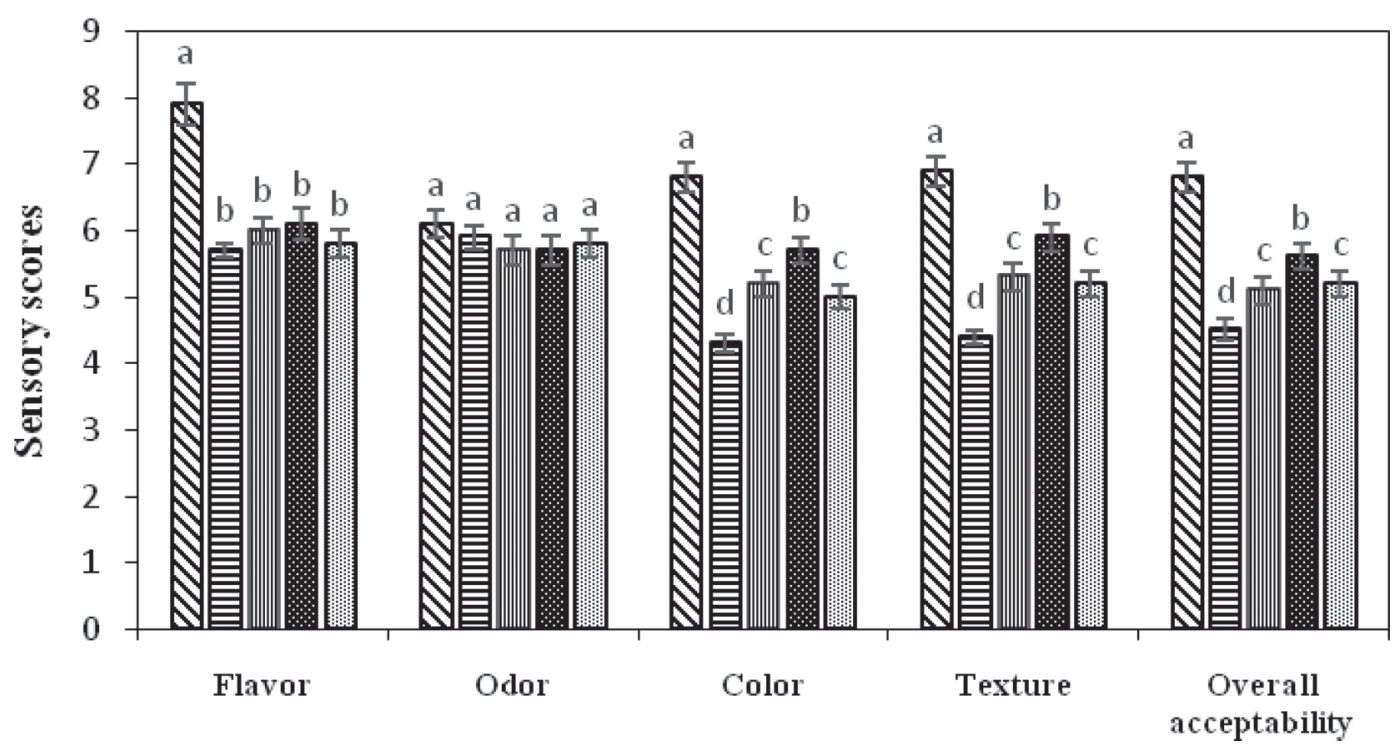

Figure 2. Sensory scores of ice cream samples. Different letters $(\mathrm{a}-\mathrm{d})$ stand for significant differences between treatments $(P<0.05)$. $\mathrm{F}=$ control full-fat ice cream; $\mathrm{R}=$ control reduced-fat ice cream; R-WPI = reduced-fat ice cream with whey protein; $\mathrm{R}-\mathrm{WPI}+\mathrm{TG}=$ reduced-fat ice cream with whey protein and transglutaminase, R-TG = reduced-fat ice cream with transglutaminase. Error bars represent SE. 
highest overall acceptability, followed by R-TG and RWPI; the latter 2 did not show a significant difference $(P>0.05$; Figure 2).

The results of our study showed that the reduced-fat ice creams fortified with whey proteins or treated with TGase had higher apparent viscosity and lower flow index than the control reduced-fat sample; however, the flow behavior of the full-fat sample was most similar to the enzyme-treated sample with no added whey protein. Adding whey protein with TGase treatment enhanced overrun and decreased hardness of reducedfat ice cream more effectively than did whey protein addition alone, which in turn led to higher texture score for R-WPI+TG sample. Whereas the R-WPI+TG ice cream received the highest score for overall acceptability of reduced-fat samples, it was not scored as favorably as the control full-fat ice cream.

\section{ACKNOWLEDGMENTS}

This work was supported by a research grant (No. 931/35) from Ramin Agriculture and Natural Resources University of Khuzestan.

\section{REFERENCES}

Adapa, S., H. Dingeldein, K. A. Schmidt, and T. J. Herald. 2000. Rheological properties of ice cream mixes and frozen ice creams containing fat and fat replacers. J. Dairy Sci. 83:2224-2229.

Aime, D. B., S. D. Arntfield, L. J. Malcolmson, and D. Ryland. 2001. Textural analysis of fat reduced vanilla ice cream products. Food Res. Int. 64:237-246.

Akalin, A. S., C. Karagözlü, and G. Ünal. 2008. Rheological properties of reduced-fat and low-fat ice cream containing whey protein isolate and inulin. Eur. Food Res. Technol. 227:889-895.

Akbari, M., M. H. Eskandari, M. Niakosari, and A. Bedeltavana. 2016. The effect of inulin on the physicochemical properties and sensory attributes of low-fat ice cream. Int. Dairy J. 57:52-55.

AOAC International. 2005. Official Methods of Analysis of AOAC International. 18th ed. AOAC International, Gaithersburg, MD.

BahramParvar, M., M. M. Tehrani, and S. M. A. Razavi. 2013. Effects of a novel stabilizer blend and presence of $\kappa$-carrageenan on some properties of vanilla ice cream during storage. Food Biosci. $3: 10-18$.

Daw, E., and R. W. Hartel. 2015. Fat destabilization and melt-down of ice creams with increased protein content. Int. Dairy J. 43:33-41.

Elsayed Metwally, A. M. M. 2007. Effect of enzymatic cross-linking of milk proteins on properties of ice cream with different composition. Int. J. Food Sci. Technol. 42:939-947.
Goudarzi, M., A. Madadlou, M. E. Mousavi, and Z. Emam-Djomeh. 2015. Formulation of apple juice beverages containing whey protein isolate or whey protein hydrolysate based on sensory and physicochemical analysis. Int. J. Dairy Technol. 68:70-78.

Karaman, S., Ö. S. Toker, F. Yüksel, M. Çam, A. Kayacier, and M. Dogan. 2014. Physicochemical, bioactive, and sensory properties of persimmon-based ice cream: Technique for order preference by similarity to ideal solution to determine optimum concentration. J. Dairy Sci. 97:97-110.

Lim, S. Y., B. G. Swanson, C. F. Ross, and S. Clark. 2008. High hydrostatic pressure modification of whey protein concentrate for improved body and texture of lowfat ice cream. J. Dairy Sci. 91:1308-1316.

Marshall, R. T., and W. S. Arbuckle. 1996. Ice Cream. 5th ed. International Thomson Publ., New York, NY.

McClements, D. J. 2015. Reduced-fat foods: The complex science of developing diet-based strategies for tackling overweight and obesity. Adv. Nutr. 6:338S-352S.

Motoki, M., and K. Seguro. 1998. Transglutaminase and its use for food processing. Trends Food Sci. Technol. 9:204-210.

Muse, M. R., and R. W. Hartel. 2004. Ice cream structural elements that affect melting rate and hardness. J. Dairy Sci. 87:1-10.

Ohmes, R. L., R. T. Marshall, and H. Heymann. 1998. Sensory and physical properties of ice creams containing milk fat or fat replacers. J. Dairy Sci. 81:1222-1228.

Prindiville, E. A., R. T. Marshall, and H. Heymann. 2000. Effect of milk fat, cocoa butter, and whey protein fat replacers on the sensory properties of lowfat and nonfat chocolate ice cream. J. Dairy Sci. 83:2216-2223.

Relkin, P., and S. Sourdet. 2005. Factors affecting fat droplet aggregation in whipped frozen protein-stabilized emulsions. Food Hydrocoll. 19:503-511.

Roland, A. M., L. G. Phillips, and K. J. Boor. 1999. Effects of fat content on the sensory properties, melting, color, and hardness of ice cream. J. Dairy Sci. 82:32-38.

Rossa, N. R., E. M. F. Sá, V. M. Burin, and M. T. Bordignon-Luiz. 2011. Optimization of microbial transglutaminase activity in ice cream using response surface methodology. LWT Food Sci. Technol. 44:29-34.

Rossa, P. N., V. M. Burin, and M. T. Bordignon-Luiz. 2012. Effect of microbial transglutaminase on functional and rheological properties of ice cream with different fat contents. LWT Food Sci. Technol. 48:224-230

Ruger, P. R., R. J. Baer, and K. M. Kasperson. 2002. Effect of double homogenization and whey protein concentrate on the texture of ice cream. J. Dairy Sci. 85:1684-1692.

Vasbinder, A. J. 2002. Casein-whey protein interactions in heated milk. PhD thesis, Department of Food Science, Utrecht University, Utrecht, the Netherlands.

Yilsay, T. Ö., L. Yilmaz, and A. A. Bayizit. 2006. The effect of using a whey protein fat replacer on textural and sensory characteristics of low-fat vanilla ice cream. Eur. Food Res. Technol. 222:171-175.

Zayas, J. F. 1997. Functionality of Proteins in Food. Springer-Verlag, Berlin, Germany. 